published in the near fuutre. ${ }^{6}$ The preliminary results of in vitro lipid haemodialysis utilizing ${ }^{14} \mathrm{C}$-imipramine indicate a clearance of approximately 20 to $40 \mathrm{ml} / \mathrm{min}$, depending on the type of filter, dialysate, and blood-line system used.-We are, etc.,

H. W. ASBACH H. W. SCHULER

Department of Urology

Germany

1 Asbach, H. W., et al., in International Congress of the European Association of Poison Control Centres and the American Association of Poison Control Centres, Aktuelle Problems der Inten-
sivmedizin, vol. I, Darmstadt, Steinkopff. In sivmedizin, vol. I, Darmstadt, Steinkopff. In
press.

Schuler, H. W., et al., Proceedings of the Euro-
pean Dialysis and Transplant Association, 1972, pean Dial. 325 .

3 Moeschlin, S., Klinik und Therapie der Vergiftungen. Stuttgart, Thieme, 1972.

Harthorne, J. W., Marcus, A. M., and Kaye, M., New England fournal of Medicine, 1963, 268, 33.

5 Bauditz, W., and Barthelheimer, H. K., Archiv für Toxikjlogie, 1970, 26, 133.

6 Asbach, H. W., Holz, F., Mohring, K., and Schuler, H. W. In preparation.

\section{Cars or Chairs?}

SIR,-Your leading article (6 April, p. 2) dealing with the Sharp Report on the mobility of physically disabled people makes the interesting point that problems caused by an inability to walk were at one time overcome by the provision of a motorized bath chair.

I suggest that there still exists a need for such a vehicle. Those unable to drive, or ineligible for a four-wheel car under the new proposals, could be provided with an outdoor electric wheel chair (for example, the Batric Power Chair), which is designed for pavement use at walking pace. At a cost per chair of about $£ 300$, alleviation of the frustrations of the physically housebound could become a financially viable proposition.-I am, etc.,

D. J. BICKLE

Guy's Hospital,

London S.E.1

\section{Treatment of Acute Gout}

SIR,-We would like to support the dose of indomethacin recommended in the Therapeutic Conference ( 9 March, p. 446). While we do not doubt the lack of toxicity of the higher dosage supported by Dr. D. I. Haslock (13 April, p. 121), we do not feel that such high doses are necessary.

We have collected evidence that in acute gout indomethacin at $150 \mathrm{mg}$ per day can produce a strikingly rapid reduction in inflammation, as assessed by an objective, quantitative, thermographic method. ${ }^{1-W e}$ are, etc.,

P. A. BACON

A. J. COLlins

E. F. J. RING

Royal National Hospital for Rheumatic Diseases, Bath

1 Collins, A. J., et al., Annals of the Rheumatic Diseases, 1974, 33, 113 .

\section{Steroid Aerosols and Candidiasis}

SIR, - The advent of effective aerosol steroids for treating asthma which do not cause systemic side effects or suppress growth has been of considerable importance to paediatricians. ${ }^{1}$ Enthusiasm for these drugs in some recently published studies has, however, been dampened by the finding of oral and even laryngeal infection with candida in as many as $13 \%$ of cases (Dr. M. K. Allen and others, 2 February, p. 171). In some patients this has required reduction of drug dosage. In our experience with children we had not encountered clinical thrush, and none of the patients affected in the study of Dr. McAllen and her colleagues was below 18 years. We therefore carried out an investigation to determine the incidence of candida among our children treated with long-term beclomethasone dipropionate and a control group of asthmatic children not receiving the drug. Each child was clinically examined and a swab was taken from all parts of the oropharynx and cultured on appropriate media.

The results are summarized in the table.

\begin{tabular}{|c|c|c|}
\hline & $\begin{array}{l}\text { Beclomethasone } \\
\text { Group }\end{array}$ & $\begin{array}{l}\text { Control } \\
\text { Group }\end{array}$ \\
\hline Number & 24 & 33 \\
\hline $\begin{array}{l}\text { Boys :girls } \\
\text { Age (years) }\end{array}$ & $\begin{array}{c}2 \cdot 3: 1 \\
8 \cdot 7 \pm 2 \cdot 8\end{array}$ & $\begin{array}{c}2 \cdot 4: 1 \\
6.9 \pm 3.1\end{array}$ \\
\hline $\begin{array}{l}\text { Duration of } \\
\text { aerosol therapy } \\
\text { (months) }\end{array}$ & $\begin{array}{c}(3-16) \\
12 \cdot 9 \pm 6 \cdot 8 \\
(2-24)\end{array}$ & $(3-0)$ \\
\hline $\begin{array}{l}\text { Dose of aerosol } \\
\text { therapy }(\mu \mathrm{g} / \text { day }) \\
\text { No. with positive } \\
\text { cultures }\end{array}$ & $\left(\begin{array}{c}\left.469 \pm \frac{245}{3} 800\right) \\
\left(100 \frac{}{3}\right.\end{array}\right.$ & $\begin{array}{l}0 \\
2\end{array}$ \\
\hline
\end{tabular}

The mean \pm 1 S.D. and the range are given.

No clinical cases of thrush were seen, but candida was isolated on five occasionsnamely, in three out of the 24 aerosol-using children and two out of the 33 control children. There was no relationship between the dose or duration of aerosol therapy and the finding of candida nor between the use of additional oral steroids or antibiotics. Though Brown and Storey ${ }^{2}$ reported thrush in four out of 31 children on beclomethasone dipropionate, they had no comparable control group. We believe that the clinical complication of candida infection does no occur as a result of aerosol steroid therapy in children and the organism may be isolated by chance in a small proportion of asthmatic children whatever their therapy. -We are, etc.,

S. GODFREY G. HAMBLETON

P. KÖNIG

Department of Paediatrics,

Hammersmith Hospital

Godfrey, S., and Konig, P., Archives of Disease in Childhood, 1973, 48, 665.

fournal, 1973, 3, 161 .

\section{Vein Stripping}

SIR,-With reference to the article by $\mathrm{Mr}$ S. J. Cox and others on nerve injuries as a result of stripping the long saphenous vein (9 March, p. 415) I feel that the question is not whether stripping is best performed up through the groin or down through the ankle but whether stripping ought to be performed at all.

My antagonism to stripping is based on the following facts: (1) First described by Galen in 150 A.D., it belongs more to antique surgery or mediaeval torture than to modern treatment. (2) The theoretical in- dications for its use in the treatment of varicose veins are weak, as inadequate perforating veins, now regarded as the cause of the disease, hardly ever communicate directly with the long saphenous vein. (3) A pathologically deformed vein with twirls and varices renders stripping virtually impossible-only normal veins can be stripped. (4) There is an appreciable risk of local postoperative complications such as haemorrhage, nerve damage, and arterial injuries (subsequent gangrene has been described). (5) One of our most easily available and increasingly used "spare parts" is destroyed. (6) Anaesthesia, admission to hospital, and a longer period on the sick list mean an economic burden for both the community and the patient.

I feel that the stripping sound is useful in removing isolated segments of vein as those under an uloer or eczematous area, but otherwise ought to be donated to a museum. Am I alone in my view?-I am, etc.,

\section{Jakobsbergs Sjukhus, \\ Stockholm}

DAVID FREEDMAN

\section{Thyopac-5 Test}

SIR,-Dr. J. G. Hardy and Mr. G. M Newble (30 March, p. 636) claim to have assessed the diagnostic accuracy of the Thyopac-5 test and that of other tests of thyroid function. It is not possible, however, to be certain of either the accuracy or the usefulness of this test from the data presented since the authors have not stated what objective criteria were finally used to distinguish between normal and abnormal thyroid function.-We are, etc.,

PATRICIA Vice DAVID EVERED

Wellcome Research Laboratories,

Royal Victoria Infirmary,

Newcastle upon Tyne

\section{Renal Lesions of Subacute Infective Endocarditis}

SIR,-Dr. J. M. Boulton-Jones and his colleagues (6 A.pril, p. 11) appear to express some surprise that renal failure was a "striking feature" in their group of five patients suffering from infective endocarditis. They do not state how their patients were selected. This complication has, of course, been recognized for many years. Harbitz in 1899 drew attention to the frequency and intensity of renal symptoms in 16 cases of infective endocarditis. ${ }^{12}$ Furthermore, the advent of antibiotics could be expected to make this complication more likely, not less likely as Dr. Boulton-Jones and his colleagues imply, because control of the infec-

tive process with prolonged survival would allow time for non-suppurative lesions to develop.

The study described by your contributors gives an elegant demonstration suggesting an immune-complex aetiology for the glomerular lesions in three of their five patients, but the cause remained undetermined in the remaining two. They do not mention the presence of other lesions, in particular that of fibrin thrombi, or lesions in other organs in the two that came to necropsy. In a series of 40 fatal cases of 